Pesq. Vet. Bras. 28(2):108-112,fevereiro 2008

\title{
Blood-gas and electrolyte values for Amazon parrots (Amazona aestiva) ${ }^{1}$
}

\begin{abstract}
Valéria V. Paula ${ }^{2^{*}}$, Denise T. Fantoni ${ }^{3}$, Denise A. Otsuki ${ }^{4}$ and José O.C. Auler $\mathrm{Jr}^{5}$
ABSTRACT.- Paula V.V., Fantoni D.T., Otsuki D.A. \& Auler Jr J.O.C. 2008. Blood-gas and electrolyte values for non-anesthetized Amazon parrots (Amazona aestiva). Pesquisa Veterinária Brasileira 28(2):108-112. Departamento de Ciências Animais, Universidade Federal Rural do Semi-Árido, BR110 Km $47 \mathrm{~s} / \mathrm{n}$, Cx. Postal 137, Presidente Costa e Silva, Mossoró, RN 59625-900, Brazil. E-mail: valeria@ufersa.edu.br

The aim was to provide reference data for blood gas/acid-base status and electrolytes for non-anesthetized Amazon parrots (Amazona aestiva). Thirty-five adult parrots from Tietê ecologic park were utilized. Arterial blood $(0.3 \mathrm{ml})$ samples were anaerobically collected from the superficial ulnar artery in heparinized (sodium heparin) 1-ml plastic syringes. The samples were immediately analyzed through a portable analyzer (i-STAT*, Abbot, Illinois, USA) with cartridges $\left(E G 7^{+}\right)$. These data were grouped in such a way as to present both mean and standard deviation: body weight $(360 \pm 37 \mathrm{~g})$, respiratory rate $(82 \pm 33 \mathrm{~b} / \mathrm{m})$, temperature $\left(41.8 \pm 0.6^{\circ} \mathrm{C}\right)$, hydrogen potential $(7.452 \pm 0.048)$, carbon dioxide partial pressure $(22.1 \pm 4.0 \mathrm{mmHg})$, oxygen partial pressure $(98.1 \pm 7.6 \mathrm{mmHg})$, base excess $(-7.9 \pm 3.1)$, plasma concentration of bicarbonate ions $(14.8 \pm 2.8 \mathrm{mmol} / \mathrm{L})$, oxygen saturation $(96.2 \pm 1.1 \%)$, plasma concentration of sodium $(147.4 \pm 2.2 \mathrm{mmol} / \mathrm{L})$, plasma concentration of potassium $(3.5 \pm 0.53 \mathrm{mmol} / \mathrm{L})$, plasma concentration of calcium $(0.8 \pm 0.28 \mathrm{mmol} / \mathrm{L})$, hematocrit $(38.7 \pm 6.2 \%)$ and concentration of hemoglobin $(13.2 \pm 2.1 \mathrm{~g} / \mathrm{dl})$. This study led us to conclude that, although the results obtained showed hypocapnia and low values of bicarbonate and base excess, when compared to other avian species, these data are very similar. Besides, in spite of the equipment being approved only for human beings, it was considered simple and very useful in the analysis of avian blood samples. By using this equipment we were able to provide references data for non-anaesthetized Amazon parrots.
\end{abstract}

INDEX TERMS: Amazona aestiva, blood gas, electrolytes.

\footnotetext{
${ }^{1}$ Received on November 12, 2007.

Accepted for publication on January 31, 2008.

2 Departamento de Ciências Animais, Universidade Federal Rural do Semi-Árido, BR $110 \mathrm{Km} 47 \mathrm{~s} / \mathrm{n}$, Cx. Postal 137, Presidente Costa e Silva, Mossoró, RN 59625-900, Brazil. Bolsista CNPq. *Corresponding author: valeria@ufersa.edu.br

${ }^{3}$ Departamento de Cirurgia, Faculdade de Medicina Veterinária, Universidade de São Paulo (USP), Cidade Universitária, Av. Prof. Dr. Orlando Marques de Paiva 87, São Paulo, SP 05508-270, Brazil.

${ }^{4}$ Laboratório de Investigação Médica LIM 08, Faculdade de Medicina, USP, Av. Dr. Arnaldo 455, Cerqueira César, São Paulo, SP 01246903.

${ }^{5}$ Disciplina de Anestesiologia, Departamento de Cirurgia, Faculdade de Medicina, USP, Av. Dr. Arnaldo 455, Cerqueira César, São Paulo, SP 01246-903.
}

RESUMO.- [Valores de gases sangüíneos e eletrólitos de papagaios-verdadeiros (Amazona aestiva).] $\mathrm{O}$ objetivo deste trabalho foi estabelecer dados de referência do equilíbrio ácido-básico e eletrólitos de papagaios (Amazonas aestiva) não anestesiados. Foram utilizados trinta e cinco papagaios oriundos do Parque ecológico do Tietê. Amostras de sangue $(0,3 \mathrm{ml})$ da artéria superficial ulnar foram coletadas em seringas plásticas $(1 \mathrm{ml})$ heparinizadas. As amostras foram analisadas imediatamente, usando um analisador portátil (i-stat*, Abbott, Illinois, USA) com cartuchos (i-stat EG7+). Os resultados foram demonstra-

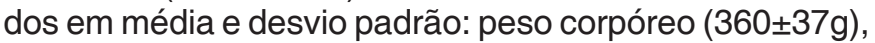
freqüência respiratória $(82 \pm 33 \mathrm{mpm})$, temperatura $\left(41,8 \pm 0,6^{\circ} \mathrm{C}\right)$, potencial hidrogeniônico $(7,452 \pm 0,05)$, pres- 
são parcial de dióxido de carbono $(22,1 \pm 4,0 \mathrm{mmHg})$, pressão parcial de oxigênio $(98,1 \pm 7,6 \mathrm{mmHg})$, excesso de base $(-7,45 \pm 3,1)$, saturação da hemoglobina $(96,2 \pm 1,1 \%)$, concentração plasmática de sódio $(147,4 \pm 2,2 \mathrm{mmol} / \mathrm{L})$, concentração plasmática de potássio $(3,5 \pm 0,53 \mathrm{mmol} / \mathrm{L})$, concentração plasmática de cálcio $(0,8 \pm 0,28 \mathrm{mmol} / \mathrm{L})$, hematócrito $(38,7 \pm 6,2 \%)$ e concentração de hemoglobina $(13,2 \pm 2,1 \mathrm{~g} / \mathrm{dl})$. Este estudo nos levou a concluir que embora os animais apresentassem hipocapnia e valores baixos de bicarbonato e excesso de bases, quando comparamos aos das outras espécies aviárias, os dados são similares. Embora o equipamento seja aprovado somente para espécie humana, foi considerado prático e útil na análise do sangue de aves. Utilizando este equipamento, fomos capazes de estabelecer dados de referência do status ácido-básico e eletrólitos de papagaios não anestesiados.

TERMOS DE INDEXAÇÃO: Amazona aestiva, gases sangüíneos, eletrólitos.

\section{INTRODUCTION}

In the last years, the interest in wild life conservation has motivated an increase in the study of the use of anesthesia in wild birds and even in domestic species (Hall et al. 2001). In Brazil many people have birds, especially parrots, in their houses. Also, in the North Hemisphere countries, the interest in tropical exotic avian has grown significantly, which makes mandatory the knowledge of their physiology and management. However, the study and research of wild birds is becoming increasingly difficult. The Instituto Brasileiro do Meio Ambiente e dos Recursos Naturais Renováveis (Brazilian Institute of Environment and Renewable Natural Resources), IBAMA, maintains a rigid control on research carried out by professionals in this area with an eye to preserving the life of these animals.

There are various procedures in veterinary medicine that demand the use of anesthesia in wild animals. This fact reaffirms the necessity of further studies of these species in order to minimize risks when such procedures are necessary. Moreover, anesthetics and other pharmacological agents, normally used as preanesthetic measures, may cause various degrees of respiratory depression as well as hypoxemia and hypercapnia. Thus, it is very important that the basal parameters of these animals be known.

Only recently, the basic aspects of clinical pathology, hematology and biochemistry have been used to diagnose illnesses in birds. However, in order to know what is normal in a certain species during a monitorial process, it is necessary to know the exact physiological parameters of the animals. Such knowledge is very scarce in birds due to the large number of species and the lack of scientific research in this area. The use of physiological data from research developed in other countries is possible, but, such data are not compatible with our animals because our climate conditions, and the handling and feeding of our animals are so different of those.
In the present report, we provide reference data for blood gas/acid-base status: $\mathrm{pH}, \mathrm{PCO}_{2}, \mathrm{PO}_{2}, \mathrm{Ht}, \mathrm{Hb}, \mathrm{Be}$, $\mathrm{HCO}_{3}{ }^{-}$and $\mathrm{SO}_{2}$; and electrolytes: $\mathrm{Na}^{+}, \mathrm{K}^{+}$and iCa for nonanaesthetized Amazon parrots.

\section{MATERIALS AND METHODS}

After the approval of the local ethics School of Veterinary Medicine and IBAMA, physical examinations were performed in Amazon parrots (Amazona aestiva) from the Tietê Ecological Park (city of São Paulo, Brazil) and those birds which did not present good health conditions were released. Thirty-five animals weighing approximately $360 \pm 37 \mathrm{~g}$ were utilized for this research.

Respiratory rate was counted based on thoracic excursion during 1 minute and body temperature was measured with a digital thermometer (Digital clinical thermometer, Omrom, China).

Arterial blood $(0.3 \mathrm{ml})$ samples were anaerobically collected from the superficial ulnar artery in heparinized $(0.01 \mathrm{ml}$ sodium heparin) $1 \mathrm{ml}$ plastic commercial syringes. The samples were immediatly analyzed for $\mathrm{pH}, \mathrm{PO}_{2}, \mathrm{PCO}_{2}$, sodium $\left(\mathrm{Na}^{+}\right)$, potassium $\left(\mathrm{K}^{+}\right)$, ionized Calcium (iCa) and hematocrit (Hct) measurement, through a portable analyzer (i-STAT, Abbott, Illinois, USA) with cartridges (EG7 ${ }^{+}$, Abbott, Illinois, USA). The analyzer also calculated sample bicarbonate concentration $\left(\mathrm{HCO}_{3}^{-}\right)$, base excess $(\mathrm{BE})$ and oxygen saturation $\left(\mathrm{SaO}_{2}\right)$ values. Blood gas values were corrected to the cloacal temperature. Each day, before utilization, the i-STAT analyzer was checked with an electronic simulator.

These data were grouped and expressed with both mean and standard deviation (SD).

\section{RESULTS}

Body weight, respiratory rate, temperature, hydrogen potential $(\mathrm{pH})$, partial carbon dioxide pressure $\left(\mathrm{pCO}_{2}\right)$, partial oxygen pressure $\left(\mathrm{pO}_{2}\right)$, base excess $(\mathrm{BE})$, concentration of bicarbonate ions $\left(\mathrm{HCO}_{3}{ }^{-}\right)$, oxygen saturation $\left(\mathrm{SO}_{2}\right)$, serum concentration of sodium $\left(\mathrm{Na}^{+}\right)$, serum concentration of potassium $\left(\mathrm{K}^{+}\right)$, serum concentration of calcium (iCa), hematocrit $(\mathrm{Ht})$ and serum concentration of hemoglobin $(\mathrm{Hb})$ of non-anesthetized parrots are summarized in Table 1.

\section{DISCUSSION}

We worked with a portable analyzer (i-STAT*, Abbott, Illinois, USA) which requires only a small volume of blood $(0.95 \mathrm{ml})$ and allows numerous blood analyses to be done, depending on the type of cartridges used. The principal advantage of this equipment is that it is portable and easy to use. The only recommendation is to avoid high temperatures since it does not work when temperatures are higher than $35^{\circ} \mathrm{C}$.

In small birds, collecting blood by using a syringe and needle to puncture the vein frequently results in frustration, the formation of hematoma, and even clotted samples. Most avian veins easily collapse during blood collection through a syringe. The blood often begins to clot in the syringe by the time an adequate sample is obtained. For the best results, the blood should be collected with an anticoagulant, such as EDTA 
Table 1. Values of physical characteristics, acid-base status, hematocrit $(\mathrm{Ht})$, hemoglobin $(\mathrm{Hb})$ and electrolytes of non-anesthetized Amazon parrots (Amazonas aestiva), São Paulo, 2006. Values are mean \pm SD (minimum - maximum)

\begin{tabular}{|c|c|c|}
\hline \multirow[t]{3}{*}{ Physical characteristics } & Body weight $(\mathrm{g})$ & $360 \pm 37(284-425)$ \\
\hline & Respiratory rate (breaths/min) & $82 \pm 33(32-150)$ \\
\hline & Temperature $\left({ }^{\circ} \mathrm{C}\right)$ & $41.8 \pm 0.6(40.2-43)$ \\
\hline \multirow[t]{8}{*}{ Blood gas / acid-base status } & $\mathrm{pH}$ & $7.452 \pm 0.048(7.343-7.552)$ \\
\hline & $\mathrm{PaCO}_{2}(\mathrm{mmHg})$ & $22.1 \pm 4.0(14.6-29.8)$ \\
\hline & $\mathrm{PaO}_{2}(\mathrm{mmHg})$ & $98.1 \pm 7.6(85-113)$ \\
\hline & Ht $(\%)$ & $38.7 \pm 6.2(24-50)$ \\
\hline & $\mathrm{Hb}(\mathrm{g} / \mathrm{dl})$ & $13.2 \pm 2.1(8.2-17)$ \\
\hline & $\mathrm{BE}$ & $-7.9 \pm 3.1(-15-1)$ \\
\hline & $\mathrm{HCO}_{3}^{-}(\mathrm{mmol} / \mathrm{L})$ & $14.8 \pm 2.8(9.5-21)$ \\
\hline & $\mathrm{SO}_{2}(\%)$ & $96.2 \pm 1.1(94-98)$ \\
\hline \multirow[t]{3}{*}{ Electrolytes } & $\mathrm{Na}^{+}(\mathrm{mmol} / \mathrm{L})$ & $147.4 \pm 2.2(141-150)$ \\
\hline & $\mathrm{K}^{+}(\mathrm{mmol} / \mathrm{L})$ & $3.5 \pm 0.53(2.8-4.9)$ \\
\hline & $\mathrm{iCa}(\mathrm{mmol} / \mathrm{L})$ & $0.8 \pm 0.28(0.34-1.4)$ \\
\hline
\end{tabular}

(ethyenediaminetetraacetic acid) (Campbell 1984). Instead of EDTA we utilized $0.01 \mathrm{ml}$ of heparin. The percentage of hematoma formation was very low and heparin completely avoids clot development.

Determining normal values is always difficult when working with wild species, especially birds. The small size of avian arteries makes almost impossible the use of chronic instrumentation and the remote-controlled device for sampling arterial blood described by Kawashiro \& Scheid (1975). In this study, animals were previously anesthetized and an arterial catheter was placed into the brachial artery for further analysis. In small birds such as Amazon parrots, this technique is impracticable, because, even with careful restraint, stress-related hyperventilation cause a respiratory

Table 2. Values of temperature $(\mathrm{T}){ }^{\circ} \mathrm{C}$, hydrogen potential $(\mathrm{pH})$, partial carbon dioxide pressure $\left(\mathrm{pCO}_{2}\right) \mathrm{mmHg}$, partial oxygen pressure $\left(\mathrm{pO}_{2}\right) \mathrm{mmHg}$, base excess $(\mathrm{BE})$, concentration of bicarbonate ions $\left(\mathrm{HCO}_{3}{ }^{-}\right) \mathrm{mmol} / \mathrm{L}$, oxygen saturation $\left(\mathrm{SO}_{2}\right) \%$ in different species of birds, according to the literature. A/NR = awake/not restrained; $\mathrm{A} /$ $R=$ awake/physical restraint. Values are mean $\pm S D$

\begin{tabular}{ccccc}
\hline Parameter & Author & Species & Condition & Values \\
\hline $\mathrm{T}\left({ }^{\circ} \mathrm{C}\right)$ & Ludders et al. (1990) & Duck & A/NR & $41.6 \pm 0.2$ \\
& Ludders et al. (1990) & Duck & Anesthetized & 41.30 .1 \\
& Calder \& Schmidt-Nielsen (1966) & Pigeon & A/NR & 39.7 \\
& Kawashiro \& Scheid (1975) & Hen & A/NR & $41.0 \pm 0.1$ \\
$\mathrm{pH}$ & Bech \& Johansen (1980) & Swan & A/NR & $39.5 \pm 0.3$ \\
& Ludders et al. (1990) & Duck & A/NR & $7.458 \pm 0.011$ \\
& Ludders et al. (1990) & Duck & Anesthetized & $7.312 \pm 0.017$ \\
& Calder \& Schmidt-Nielsen (1966) & Pigeon & A/NR & $7.52 \pm 0.02$ \\
& Schmitt et al. (2002) & Emu & A/NR & $7.44 \pm 0.02$ \\
& Mitchell et al. (2001) & Duck & A/R & $7.46 \pm 0.01$ \\
& Kawashiro \& Scheid (1975) & Hen & A/NR & $7.52 \pm 0.01$ \\
$\mathrm{PaCO}_{2}$ & Calder \& Schmidt-Nielsen (1968) & Roadrunner & A/NR & 7.58 \\
& Bech \& Johansen (1980) & Swan & A/NR & $7.501 \pm 0.024$ \\
& Ludders et al. (1990) & Duck & A/NR & $32.5 \pm 0.8$ \\
& Ludders et al. (1990) & Duck & Anesthetized & $57.2 \pm 4.2$ \\
& Powell et al. (2004) & Duck & A/NR & $32.4 \pm 0.4$ \\
& Calder \& Schmidt-Nielsen (1966) & Pigeon & A/NR & $28.5 \pm 2.3$ \\
& Schmitt et al. (2002) & Emu & A/NR & $31.5 \pm 1.6$ \\
& Mitchell et al. (2001) & Duck & A/R & $30.1 \pm 0.4$ \\
& Kawashiro \& Scheid (1975) & Hen & A/NR & $33.0 \pm 1.0$ \\
& Calder \& Schmidt-Nielsen (1968) & Roadrunner & A/NR & 24.5 \\
& Bech \& Johansen (1980) & Swan & A/NR & $27.1 \pm 4.1$ \\
$\mathrm{PaO}_{2}$ & Ludders et al. (1990) & Duck & A/NR & $101.3 \pm 2.0$ \\
& Ludders et al. (1990) & Duck & Anesthetized & $358.5 \pm 12.7$ \\
& Powell et al. (2004) & Duck & A/NR & $95.7 \pm 1.6$ \\
& Schmitt et al. (2002) & Emu & A/NR & $96.6 \pm 4.8$ \\
& Mitchell et al. (2001) & Duck & A/R & $100.0 \pm 1.2$ \\
& Kawashiro \& Scheid (1975) & Hen & A/NR & $82.0 \pm 2.0$ \\
& Bech \& Johansen (1980) & Swan & A/NR & $91.3 \pm 8.7$ \\
& Ludders et al. (1990) & Duck & A/NR & $21.8 \pm 0.6$ \\
& Ludders et al. (1990) & Duck & Anaesthetized & $26.6 \pm 1.2$ \\
& & & &
\end{tabular}


Table 3. Serum values of calcium (iCa), potassium $\left(\mathrm{K}^{+}\right)$and sodium $\left(\mathrm{Na}^{+}\right)$from different species of birds, according to the literature. Values are minimum and maximum intervals

\begin{tabular}{ccccc}
\hline Author & Species & $\mathrm{Ca}(\mathrm{mg} / \mathrm{dl})$ & $\mathrm{K}^{+}(\mathrm{meq} / \mathrm{l})$ & $\mathrm{Na}^{+}(\mathrm{meq} / \mathrm{l})$ \\
\hline Woerpel \& Rosskopf (1984) & African grey parrots & $8.0-13.0$ & $2.6-4.2$ & $134-152$ \\
Woerpel \& Rosskopf (1984) & Blue-headed parrots & $10.0-15.0$ & $3.0-4.5$ & $130-150$ \\
Woerpel \& Rosskopf (1984) & Grand eclectus parrots & $9.0-16.0$ & & \\
Woerpel \& Rosskopf (1984) & Domestic ducks & $10.0-18.0$ & $3.0-4.5$ & $130-150$ \\
Boussarie et al (2002) & Amazon parrots & $8.5-11$ & & \\
Boussarie et al (2002) & Arara & $8.3-11$ & & $148.7 \pm 5.1$ \\
Bashir \& Javed (2005) & Quail & & &
\end{tabular}

alkalosis. Although $\mathrm{PaCO}_{2}$ and $\mathrm{pH}$ range from 14.6$29.8 \mathrm{mmHg}$ and 7.343-7.552 respectively, $\mathrm{PaO}_{2}$ has a less expressive variation, $85-113 \mathrm{mmHg}$. Though these values are close to those reported in the literature, some discrepancies may be recognized, mainly in $\mathrm{PaCO}_{2}$ values. These differences can be attributed to respiratory changes induced by sampling procedures. Even $\mathrm{PaCO}_{2}$ in undisturbed resting birds, as reported by different authors, show different values (Table 2), Calder \& Schmidt-Nielsen (1968) obtained a $\mathrm{PaCO}_{2}$ value of $24.5 \mathrm{mmHg}$ in a resting roadrunner. Even though our $\mathrm{PaCO}_{2}$ present low values, they are not out of the range of normalcy. The presence of respiratory alkalosis during hyperventilation can justify the increased of the $\mathrm{pH}$. However, in our study, $\mathrm{pH}$ was $7.452 \pm 0.048$ and base excess was $-7.9 \pm 3.1 \mathrm{mmol} / \mathrm{L}$, both compatible with those in literature. The serum concentration of bicarbonate observed in this study $(14.8 \pm 2.8 \mathrm{mmol} / \mathrm{L})$ is explained by acute hyperventilation with hypocapnia, causing a small early reduction in serum bicarbonate due to cellular uptake of bicarbonate.

$\mathrm{PaO}_{2}$ values are similar to those reported by other authors (Table 2) in different avian species. Only data from Ludders et al. (1990) observed in anesthetized ducks differs from others in literature. These differences are explained by inspiratory fraction of oxygen during anesthesia. These anesthetized animals had also a higher $\mathrm{PaCO}_{2}$, probably result from respiratory depression.

Calcium is the most abundant chemical element in the body. Circulating calcium consists of a protein-bound fraction $(40 \%)$, a chelated fraction (10\%) and an ionized fraction $(50 \%)$, which is a physiologically active and homeostatically regulated component. The ionized fraction is essential to normal excitation-contraction coupling, a proper functioning of muscle tissue, ciliary movement, mitosis, neurotransmitter release, enzyme and hormonal secretion (Guyton \& Hall 1996). Low calcium levels may be seen in advanced nutritional hyperparathyroidism, parathyroiditis, renal failure, and in the idiopathic hypocalcaemia syndrome of the African Grey parrot, which may be a species with specific manifestation of adrenal disease. Hens exhibit increased calcium levels prior to egg-laying. Blood calcium levels lower than $6.0 \mathrm{mg} / \mathrm{dl}$ usually result in convulsion in psittacine birds. Levels between $6.0-8.0 \mathrm{mg} / \mathrm{dl}$ may result in weakness (Woerpel \& Rosskopf 1984). Reference values of ionized calcium for avian species were not found in literature, only total calcium values. Our results indicate values of ionized calcium of $0.8 \pm 0.28$, in parrots, minor of the normal human values $(1.0-1.15 \mathrm{mmol} / \mathrm{L})$. These lower values could be explained by the heparin binding to the calcium. Each heparin unit added to each $\mathrm{ml}$ of blood can reduce ionized calcium in $0.01 \mathrm{mmol} / \mathrm{L}$. The quantity of heparin utilized and the small amount of blood collected could result in a decrease in calcium levels. Furthermore, acute alkalemia increases protein-bound calcium (i.e., decreases ionized calcium). The respiratory alkalemia showed in our data may have contributed to these calcium levels. Potassium and sodium levels found in this study $(3.5 \pm 0.53 \mathrm{~mol} / \mathrm{L}$ and $147.4 \pm 2.2 \mathrm{mmol} / \mathrm{L}$, respectively) were similar to those found in other species (Table 3).

Evaluation of the avian hemogram has become a useful tool in the diagnosis of avian diseases. The routine use of hematological methods for human and domestic mammalian medicine has led to the development and use of avian hematology. Most caged birds have a PCV (packed cell volume, hematocrit) of $35-55 \%$. A PCV of less than $35 \%$ indicates anemia, and one greater than $55 \%$ indicates dehydration. The parrots in this study showed values $(38.7 \pm 6.2 \%)$ very similar to the literature (Table 4$)$. Hemoglobin levels $(13.2 \pm 2.1 \mathrm{~g} / \mathrm{dl})$ were also similar to the values reported in other birds.

Even though i-STAT is approved only when used on human beings, some researches have been carried it out in other species such as horses and dogs. Our results were similar to those found in the literature which refers to conventional methods. The equipment utilized is useful for the analysis of avian blood samples, and we were able to provide reference data for blood gas/acid-base status: $\mathrm{pH}, \mathrm{PCO}_{2}, \mathrm{PO}_{2}, \mathrm{Ht}, \mathrm{Hb}, \mathrm{Be}, \mathrm{HCO}_{3}^{-}$and $\mathrm{SO}_{2}$; and electrolytes: $\mathrm{Na}^{+}, \mathrm{K}^{+}$and $\mathrm{iCa}$ for non-anaesthetized Amazon parrots.

Table 4. Hematological references for hematocrit and hemoglobin ranges of common psittacine species, based on the California Avian Laboratory (Fudge 1997). Values are minimum - maximum

\begin{tabular}{ccc}
\hline Species & Hematocrit $\%$ & Hemoglobin $\mathrm{g} / \mathrm{dl}$ \\
\hline African grey parrots & $38-48$ & $11.0-16$ \\
Amazon parrots & $37-50$ & $11.0-17.5$ \\
Cockatoo & $38-48$ & $11.5-12$
\end{tabular}


Considering the threat of extinction of various species of birds from Brazilian forests, the knowledge of physiological data of these animals is of paramount importance. Literature provides us data from research developed in other countries but it is necessary to respect differences between species and environment, including handling and feeding of the animals. The data obtained in this study may help to further studies concerning biology of these animals.

\section{REFERENCES}

Bashir M. \& Javed M.T. 2005. Effects of ethanol on brain and pancreas weight, serum sodium and potassium, and haematological parameters in quail (Coturnix coturnix japonica). Avian Pathol. 34(2):96-100.

Bech C. \& Johansen K. 1980. Ventilation and gas exchange in the mute swan, Cygnus olor. Respir. Physiol. 39:285-295.

Boussarie D., Schilliger L. \& Rival F. 2002. Vade Mecum d'Anesthesie des Nouveaux Animaux de Compagnie. Med'Com editeur, Lyon. 128p.

Calder W.A. \& Schmidt-Nielsen K. 1966. Evaporative cooling and respiratory alkalosis in the pigeon. Proc. Natl. Acad. Sci. 55:750-756.

Calder W.A. \& Schmidt-Nielsen K. 1968. Panting and blood carbon dioxide in birds. Am. J. Physiol. 215(2):477-482.

Campbell T.W. 1984. Diagnostic cytology in avian medicine. Vet. Clin. North Am., Small Anim. Pract. 14(2):317-344.

Fudge A.M. 1997. Avian clinical pathology: Hematology and chemistry, p.142-157. In: Altman R.B., Clubb S.L., Dorrestein G.M. \& Quesenberry K. (ed.), Avian Medicine and Surgery. W.B. Saunders, Philadelphia.

Guyton A.C. \& Hall J.E. 1996. Parathyroid hormone, calcitonin, calcium and phosphate metabolism, vitamin D, bone and teeth, p.985-1002. In: Guyton A.C. \& Hall J.E. (ed.),Textbook of Medical Physiology. $9^{\text {th }}$ ed. W.B. Saunders, Philadelphia.

Hall L.W., Clarke K.W. \& Trim C.M. 2001. Veterinary Anaesthesia. 10th ed. W.B. Saunders, Philadelphia. 561p.

Kawashiro T. \& Scheid P. 1975. Arterial blood gases in undisturbed resting birds: measurements in chicken and duck. Respir. Physiol. 23:337-342

Ludders J.W., Mittchell G.S. \& Rode J. 1990. Minimal anesthetic concentration and cardiopulmonary dose response of isoflurane in ducks. Vet. Surg. 19(4):304-307.

Mitchell G.S., Powell F.L., Hopkins S.R. \& Milsom W.K. 2001. Time domains of the hypoxic ventilatory response in awaken ducks: episodic and continuous hypoxia. Respir. Physiol. 124:117-128.

Powell F.L., Shams H., Hempleman S.C. \& Mitchell G.S. 2004. Breathing in thin air: acclimatization to altitude in ducks. Respir. Physiol. Neurobiol. 144:225-235.

Schmitt P.M., Powell F.L. \& Hopkins S.R. 2002. Ventilation-perfusion inequality during normoxic and hypoxic exercise in the emu. J. Appl. Physiol. 93:1980-1986.

Woerpel R.W. \& Rosskopf Jr W.J. 1984. Clinical experience with avian laboratory diagnostics. Vet. Clin. North Am., Small Anim. Pract. 14(2): 249-286. 